\title{
PERIZINAN BERBASIS ONLINE SINGLE SUBMISSION UNTUK MEWUJUDKAN KEMUDAHAN BERUSAHA
}

\author{
Rio Christiawan \\ Fakultas Hukum, Universitas 17 Agustus 1945 Jakarta \\ Jalan Sunter Permai Raya Nomor 36, Jakarta Utara, 14350 \\ rchristiawan@gmail.com
}

\begin{abstract}
The main obstacle in realizing the ease of doing business in Indonesia is the problem of licensing in doing business. Government has issued PP Number 24 of 2018 concerning Electronic Integrated Business Licensing Services and also Presidential Instruction Number 7 of 2019 concerning Acceleration of Ease of Doing Business. The purpose of this research is find solution for Online Single Submission (OSS) optimalization which are important for business continuity considering that until now OSS can only be used to manage a small number of licenses. OSS will be able to encourage the level of ease of doing business in Indonesia if the OSS-based licensing process has fulfilled the essence of single submission itself, which is able to integrate licensing management and can fulfill data sharing functions.
\end{abstract}

Keywords: Licensing Obstacles; Bureaucracy; OSS; Ease of Doing Business.

\begin{abstract}
Abstrak
Kendala utama dalam mewujudkan kemudahan berusaha di Indonesia adalah masalah perizinan dalam berusaha. Pemerintah telah melahirkan PP Nomor 24 Tahun 2018 tentang Pelayanan Perizinan Berusaha Terintegrasi secara Elektronik. Instruksi Presiden Nomor 7 Tahun 2019 tentang Percepatan Kemudahan Berusaha. Tujuan penulisan ini adalah melihat persoalan bahwa Online Single Submission (OSS) masih belum dapat melayani perizinan teknis yang penting bagi kelangsungan usaha mengingat hingga saat ini OSS hanya dapat dipergunakan untuk mengurus sebagian kecil perizinan yang memang mudah dan murah untuk diurus. OSS akan dapat mendorong tingkat kemudahan berusaha di Indonesia apabila dalam pengurusan perizinan berbasis OSS telah memenuhi hakikat single submission itu sendiri, yakni dapat mengintegrasikan pengurusan perizinan dan dapat memenuhi fungsi data sharing antar instansi sehingga pengurusan perizinan sederhana, mudah, dan cepat.
\end{abstract}

Kata Kunci: Kendala Perizinan; Birokrasi; OSS; Kemudahan Berusaha.

\section{A. Pendahuluan}

Latar belakang dari penggunaan Online Single Submission (OSS) untuk pengurusan perizinan karena hambatan utama dari investasi di Indonesia adalah rumitnya birokrasi pengurusan perizinan dan pengurusan perizinan yang cenderung koruptif (Osenboorg, 2020). Demikian juga perizinan di Indonesia yang merupakan bagian dari pelayanan sektor publik selalu memiliki kendala utama yakni persoalan panjangnya pengurusan birokrasi dan persoalan birokrasi tersebut pada akhirnya akan melahirkan ketidakpastian hukum bagi masyarakat yang akan mengurus perizinan (Sutedi, 2011). Pada akhirnya dengan panjangnya birokrasi selain akan menyebabkan panjangnya jangka waktu juga akan menyebabkan perbuatan menyimpang seperti perilaku koruptif (Berger, 2013). Kondisi tersebut sama dengan apa yang 
tertera dalam laporan tahun Komisi Pemberantasan Korupsi (KPK) yang menunjukkan bahwa korupsi di sektor perizinan masih menduduki 5 besar dalam modus perbuatan korupsi yang paling sering dilakukan sepanjang 2015 - 2019 (Raharjo, 2019).

Persoalan perizinan tersebut menyebabkan kendala dalam meningkatkan jumlah investasi di Indonesia, mengingat investor akan terkendala oleh birokrasi pengurusan perizinan yang tidak memiliki ukuran yang jelas. Di samping itu jumlah perizinan yang harus diurus untuk memulai usaha di Indonesia termasuk yang terbanyak di dunia (Tim Sosialisasi BKPM, 2019). Kendala pengurusan perizinan tersebut merupakan persoalan yang serius bagi investor maupun bagi persoalan kemudahan berusaha di Indonesia.

Keputusan untuk berinvestasi dari investor akan sangat tergantung pada tingkat kemudahan berusaha. Persoalan kemudahan berusaha di Indonesia pada 2018 dan 2019 hanya menyisakan persoalan perizinan dan kepastian hukum. Dalam hal ini sulitnya dan tidak adanya ukuran yang pasti dalam pengurusan perizinan akan mempengaruhi minat investor untuk berinvestasi. Dalam perspektif investor, persoalan sulitnya pengurusan perizinan dan ketidakpastian hukum akan menyebabkan pada gangguan bisnis, investor berpandangan persoalan kemudahan berusaha khususnya terkait pengurusan perizinan sangatlah penting karena akan dapat berisiko pada gangguan bisnis (business interruption) (Lestari \& Djanggih, 2019).

Guna mengatasi persoalan tersebut pemerintah menerbitkan Peraturan Pemerintah Nomor 24 Tahun 2018 tentang Pelayanan Perizinan Berusaha Terintegrasi secara Elektronik dan Instruksi Presiden Nomor 7 Tahun 2019 tentang Percepatan Kemudahan Berusaha. Tujuan dari penerbitan kedua instrumen hukum tersebut adalah menyederhanakan pengurusan perizinan sehingga dapat mewujudkan kemudahan berusaha. Salah satu bentuk penyederhanaan pengurusan perizinan adalah melalui perizinan usaha terintegrasi secara elektronik (Online Single Submission/ OSS).

Faktanya saat ini setelah pemerintah memberlakukan pengurusan perizinan melalui OSS namun tingkat kemudahan berusaha di Indonesia tetap stagnan di peringkat ke 73 di tahun 2018 dan 2019. Bahkan setelah berlakunya PP Nomor 24 Tahun 2018 persoalan pengurusan perizinan di Indonesia masih menjadi pangkal persoalan dalam mewujudkan kemudahan berusaha di Indonesia. Hal ini terlihat pada laporan kemudahan berusaha di Indonesia tahun 2019 yang justru mengalami penurunan pada bagian perizinan dan kepastian hukum, dari tahun 2018 pada subperizinan dan kepastian hukum berada pada peringkat 118 dari 187 negara, namun pada tahun 2019 pada bidang tersebut justru turun pada peringkat 147 dari 187 negara (Lucas, 2020), sehingga meskipun pada bidang yang lain di Indonesia mengalami perbaikan namun peringkat Indonesia tetap stagnan di peringkat 73 .

Tujuan penulisan ini adalah melihat persoalan bahwa OSS masih belum dapat melayani perizinan teknis yang penting bagi kelangsungan usaha mengingat hingga saat ini OSS hanya dapat dipergunakan untuk mengurus sebagian kecil perizinan yang memang mudah dan murah untuk diurus. Masalah utama yang dianalisis dan diteliti adalah persoalan mengenai bagaimanakah mewujudkan OSS yang memiliki fungsi data sharing? Persoalan ini belum pernah diteliti sebelumnya, mengingat penelitian atau artikel ilmiah yang ada sebelumnya hanya meneliti mekanisme OSS dan perbedaan pengurusan perizinan melalui OSS dan secara konvensional. Demikian juga kebaharuan penulisan ini adalah analisis mengenai data sharing setelah berlakunya Omnibus Law yakni UndangUndang Nomor 11 Tahun 2020 tentang Cipta Kerja. 


\section{B. Pembahasan}

\section{Evaluasi Pelaksanaan OSS}

Semangat untuk menyederhanakan perizinan sebagai bentuk mewujudkan kemudahan berusaha di Indonesia pada awalnya tercantum di dalam Peraturan Presiden Nomor 91 Tahun 2017 tentang Percepatan Pelaksanaan Berusaha. Peraturan Pemerintah Nomor 24 Tahun 2018 tentang Pelayanan Perizinan Berusaha Terintegrasi secara Elektronik dan Instruksi Presiden Nomor 7 Tahun 2019 tentang Percepatan Kemudahan Berusaha merupakan bentuk landasan secara operasional dari Peraturan Presiden Nomor 91 Tahun 2017. Dalam hal ini salah satu cara untuk mewujudkan kemudahan berusaha adalah dengan menggunakan model pelayanan perizinan berusaha terintegrasi secara elektronik.

Dalam Pasal 1 ayat (5) Peraturan Pemerintah Nomor 24 Tahun 2018, yang dimaksud dengan Perizinan Berusaha Terintegrasi secara Elektronik atau Online Single Submission yang selanjutnya disingkat OSS adalah "perizinan berusaha yang diterbitkan oleh lembaga OSS untuk dan atas nama menteri, pimpinan lembaga, gubernur, atau bupati/wali kota kepada Pelaku Usaha melalui sistem elektronik yang terintegrasi."

Secara hukum, unsur yang terdapat di dalam definisi OSS tersebut ada dua hal yakni pengurusan perizinan melalui sistem elektronik dan pengurusan perizinan secara terintegrasi. Pengurusan perizinan secara elektronik dimaksudkan untuk mempersingkat birokrasi pengurusan perizinan sekaligus mengantisipasi kemungkinan penyimpangan pada praktik pengurusan perizinan. Sedangkan terintegrasi artinya jumlah perizinan yang harus diurus pada satu bidang usaha dapat dikurangi karena adanya fungsi data sharing pada perizinan terintegrasi secara elektronik.

Singapura yang kini memiliki tingkat kemudahan berusaha terbaik di Asia Tenggara merupakan pionir model pengurusan perizinan secara elektronik (OSS) sejak awal tahun 2000 dan hasilnya pengurusan perizinan di Singapura saat ini terbilang sangat cepat dengan jumlah perizinan yang tidak banyak. Hal ini terjadi karena fungsi dari data sharing sehingga investor tidak perlu mengulang pengurusan perizinan yang berbeda dengan syarat dan tujuan yang sama (Yong, 2019).

Persoalan tidak optimalnya pelaksanaan pengurusan perizinan melalui OSS di Indonesia disebabkan karena tidak semua perizinan dapat diurus secara elektronik dan belum adanya fungsi integrasi dan data sharing pada masing-masing instansi dalam pengurusan perizinan. Melalui Surat Edaran (SE) Kepala Badan Koordinasi dan Penanaman Modal (BKPM) Nomor 5743/A.8/B.1/2019 tertanggal 17 Oktober 2019 tentang Rencana Penerapan Sistem Online Single Submission (OSS) versi 1.1, melalui surat tersebut dinyatakan bahwa OSS masih perlu diperbaiki karena masih belum dapat menjalankan fungsi data sharing dan mewujudkan perizinan yang terintegrasi untuk kemudahan berusaha sehingga OSS kembali harus ditingkatkan dari versi 1.0 menjadi versi 1.1 .

Dua hal yang menjadi persoalan utama dari OSS versi 1.0, yang pertama yakni persoalan teknis dan persoalan kedua terkait sinkronisasi perizinan untuk menuju pada makna single submission itu sendiri. Dua persoalan tersebut terjelma dalam makna online single submission itu sendiri, persoalan pertama, terkait hal teknis maka persoalan tersebut terkait aspek (online) yakni terkait teknis pendaftaran, pengisian, dan pengklasifikasian usaha sehingga investor dapat melakukan kegiatan tersebut secara online.

Jika menelaah lampiran I Surat Edaran (SE) BKPM bernomor 5743/A.8/B.1/2019 nampaknya persoalan teknis (terkait aspek online) akan mengalami perbaikan yang signifikan sehingga persoalan teknis penggunaan OSS sudah akan lebih baik pada versi 1.1. Lampiran I SE BKPM tersebut memuat matriks perbedaan antara OSS versi 1.0 dan versi 1.1. Jika menelaah matriks tersebut nampaknya OSS versi 1.1 hanya akan mengalami perbaikan di sektor teknis, 
yakni formalitas pengisian isian dalam OSS sehingga menghindari kesalahan teknis yang membuat akses pada OSS memakan waktu.

Persoalan pengurusan perizinan yang belum terselesaikan hingga saat ini adalah masalah sinkronisasi perizinan untuk menuju pada makna single submission itu sendiri, hal ini nampaknya belum terjawab dalam OSS versi 1.1 jika melihat pada matriks perbedaan sebagaimana diuraikan dalam lampiran I SE BKPM tersebut. OSS versi 1.1 hanya menyelesaikan sebagian saja persoalan dari OSS versi 1.0, namun OSS versi 1.1 belum dapat dikatakan sepenuhnya menyelesaikan kendala perizinan yang menjadi menghambat investasi.

Pengurusan perizinan melalui model single submission merupakan insentif yang menarik bagi investor dan akan memiliki korelasi yang positif terhadap peringkat kemudahan berusaha. Model single submission akan mengurangi risiko gangguan bisnis (business interruption) yang disebabkan oleh sulitnya pengurusan perizinan (Ping, 2017). Di Indonesia sulitnya menerapkan pengurusan perizinan model single submission disebabkan karena model pemerintahan otonomi daerah sehingga kewenangan pemberian perizinan sebagian besar berada pada pemerintah daerah (Pudyatmoko, 2009).

Perizinan teknis tersebut biasanya diatur melalui peraturan daerah, peraturan bupati, maupun peraturan gubernur. Hampir seluruh pengurusan perizinan dilakukan di daerah dan (bahkan) di pusat tidak memiliki acuan dan jangka waktu yang jelas dan disebutkan dalam undang-undang. Hal ini menyebabkan subjektivitas pada pengurusan perizinan sangatlah tinggi, sebagaimana disebutkan Pompey (2010) bahwa subjektivitas merupakan awal dari praktik koruptif. Situasi demikian ditunjang dengan adanya kewajiban pertimbangan teknis dan rekomendasi teknis dari kepala dinas terkait sebelum kepala daerah menerbitkan perizinan teknis.

Pertimbangan teknis dan rekomendasi teknis tidak semuanya memiliki payung hukum, justru sebagian besar merupakan birokrasi yang diciptakan oleh masingmasing daerah, yang akibatnya menambah panjang birokrasi dan lamanya mengurus perizinan teknis. Misalnya sejak era otonomi daerah seharusnya kewenangan pemberian izin lokasi merupakan wewenang kepala daerah dan tidak ada kewajiban untuk memperoleh pertimbangan teknis maupun rekomendasi teknis dari Badan Pertanahan Nasional (BPN) setempat, namun kenyataan di lapangan rekomendasi tersebut disyaratkan (Departemen Dalam Negeri Republik Indonesia, 2015).

Salah satu dampak dari berlakunya desentralisasi tersebut adalah membuat BKPM hanya dapat menginventarisir jumlah investasi, namun BKPM tidak dapat berfungsi sebagaimana mestinya karena wewenang perizinan dan pemberian fasilitas investasi ada pada provinsi maupun kabupaten/ kota. Penerbitan perizinan selalu terkait dengan kewenangan yang dimiliki oleh badan/ instansi berdasarkan peraturan perundangan. Adanya kewenangan daerah untuk menciptakan perizinan yang dipersyaratkan, maupun menerbitkan perizinan banyak berasal dari Peraturan Daerah (Perda) demikian juga dengan pengawasan terhadap pemenuhan perizinan yang dipersyaratkan. Jika dirunut lebih lanjut dalam hal ini Perda adalah produk hukum yang dikenal setelah berlakunya UU Otonomi Daerah.

Saat ini tantangan utama BKPM sebagai instansi yang membidangi pengurusan perizinan online single submission adalah mewujudkan konsep single submission itu sendiri. Artinya dalam mewujudkan konsep single submission maka pemerintah pusat melalui BKPM harus melakukan penataan kewenangan penerbitan perizinan, dalam hal ini termasuk pada penataan di tingkat pemerintah daerah. Faktanya hingga saat ini 80 persen perizinan masih diurus secara tatap muka dan tidak melalui sistem OSS, demikian juga hingga saat ini belum ada pengurusan perizinan yang terintegrasi (Lahadila, 2019).

Guna mewujudkan kemudahan berusaha maka konsep single submission 
tersebut harus dapat diterapkan, sebaliknya jika esensi single submission belum dapat diterapkan maka persoalan perizinan yang menjadi kendala bagi kepastian hukum berusaha belum dapat diatasi dan hal ini tentu menjadi faktor yang negatif bagi kemudahan berusaha di Indonesia. Tanpa terpenuhinya faktor single submission dalam pengurusan perizinan maka kemudahan berusaha tetap tidak akan dapat dicapai, karena risiko ketidakpastian dalam pengurusan perizinan masih sangat tinggi dan hal tersebut akan menciptakan gangguan dalam berusaha (business interruption) (Arrum, 2019).

Makna dari single submission yang harus diwujudkan adalah menuju pengurusan perizinan terpadu, terintegrasi, dan mewujudkan data sharing antar instansi. Tanpa adanya pengurusan perizinan yang terintegrasi maka kemudahan berusaha tidak akan dapat diwujudkan karena investor masih harus berhadapan dengan panjangnya birokrasi pengurusan perizinan yang penuh ketidakpastian (Tim Sosialisasi OSS, 2018). Dalam hal ini yang dipandang kontradiktif dengan upaya mewujudkan kemudahan berusaha adalah faktor tumpang tindih dan banyaknya perizinan yang harus diurus serta panjangnya prosedur pengurusan (birokrasi) pengurusan perizinan yang dimaksud.

Upaya untuk meringkas jumlah perizinan yang akan diurus tersebut maupun upaya untuk meringkas prosedur (lamanya) tahapan pengurusan perizinan akan dapat diwujudkan jika pengurusan perizinan dengan model OSS dapat mengakomodir fungsi data sharing antar instansi sehingga dapat mengurai birokrasi yang panjang dalam pengurusan perizinan. Demikian juga data sharing juga dipandang dapat mewujudkan kepastian hukum karena memberi landasan data yang sama pada setiap instansi dalam pengurusan perizinan.

Data sharing antar instansi juga dapat dipergunakan untuk mewujudkan sifat pengurusan perizinan yang terintegrasi artinya investor tidak perlu mengurus perizinan yang sifatnya pengulangan pada instansi yang berbeda, sehingga baik jumlah perizinan yang harus diurus maupun prosedur tahapan pengurusan perizinan juga dapat diringkas dengan adanya data sharing antar instansi.

\section{Penataan Kewenangan untuk Optimalisasi OSS}

Penggunaan pelayanan perizinan berusaha terintegrasi secara elektronik tidak akan optimal jika tanpa disertai dengan penataan kewenangan masing-masing instansi yang terkait dengan penerbitan perizinan. Saat ini OSS tidak dapat berfungsi optimal karena OSS belum dapat mewujudkan perizinan terpadu dan terintegrasi, serta OSS belum dapat menciptakan data sharing antar instansi yang dapat meringkas jumlah perizinan berusaha maupun meringkas tahapan pengurusan perizinan berusaha.

Dalam pandangan investor jika jumlah perizinan yang diperlukan dan semakin sedikit dan waktu pengurusan serta tahapan untuk pengurusan semakin pendek maka akan semakin menunjukkan adanya kepastian hukum pada investor dan menunjukkan tingkat kemudahan berusaha yang lebih baik (Brigs, 2015). Artinya mutlak saat ini bagi pemerintah untuk kembali memperbaiki sistem pelayanan perizinan berusaha terintegrasi secara elektronik (OSS) sehingga dapat mewujudkan perizinan yang terintegrasi dan data sharing antar instansi.

Penyebab utama tidak dapat berfungsinya OSS sebagai pelayanan terintegrasi dan mewujudkan data sharing (satu kesatuan data) adalah terbitnya PP Nomor 24 Tahun 2018 tentang Pelayanan Perizinan Berusaha Terintegrasi secara Elektronik dan Instruksi Presiden Nomor 7 Tahun 2019 tentang Percepatan Kemudahan Berusaha tidak disertai dengan penataan kewenangan instansi yang memiliki kewenangan dalam penerbitan perizinan yang diperlukan dalam berusaha. Akibatnya OSS tidak dapat melayani investor secara optimal dan sebagian besar perizinan masih diurus secara manual di masing-masing instansi. 
Sebagai tindak lanjut dari kedua produk hukum tersebut maka saat ini pemerintah harus mengadakan penataan kewenangan. Penataan kewenangan dalam rangka penerbitan perizinan harus dibarengi dengan sinkronisasi peraturan perundang-undangan karena kewenangan pemberian izin maupun rekomendasi terkait pemberian izin diberikan oleh perundang-undangan (Harun, 2014). Tanpa adanya penataan kewenangan penerbitan perizinan melalui sinkronisasi peraturan perundang-undangan maka pelayanan perizinan berusaha terintegrasi secara elektronik tidak akan dapat diwujudkan dalam tataran praktik.

Penataan kewenangan penerbitan perizinan harus dilakukan dengan cara sinkronisasi peraturan perundang-undangan. Dengan demikian peraturan perundangan yang melahirkan kewenangan yang tumpang tindih akan dapat disederhanakan. Dalam hal ini semakin sedikit kewenangan yang diberikan oleh peraturan perundangan maka akan dapat mengurai persoalan tumpang tindih kewenangan. Perlu dipahami dalam konsep administrasi negara bahwa banyaknya perizinan, lahir dari tumpang tindih kewenangan, demikian juga dalam hal ini tumpang tindih kewenangan bersumber dari tumpang tindih peraturan perundangundangan.

Misalnya peraturan menteri pertanian menyatakan Izin Usaha Perkebunan (IUP) diberikan tanpa adanya batas waktu, yakni selama investor masih menjalankan usaha perkebunan kelapa sawit, namun nyatanya di beberapa daerah misalnya Kalimantan Tengah masih terdapat IUP dengan batasan masa berlaku. Hal ini terjadi karena setiap perizinan teknis yang akan terbit selalu melewati fase persetujuan rapat koordinasi antar - Satuan Kerja Perangkat Daerah (SKPD) yang tidak dibatasi jumlahnya.

Rapat koordinasi ini di satu sisi memiliki makna positif yakni merupakan bentuk kehati-hatian dan check and recheck antar instansi terkait sebelum perizinan diterbitkan kepala daerah. Sebagaimana diuraikan oleh Lotulung (2013) bahwa pada prinsipnya secara administrasi negara bahwa penerbitan perizinan merupakan pembolehan hal yang dilarang. Selain itu investor juga masih harus berhadapan dengan budaya 'paraf koordinasi' sebelum izin diberikan pada pemohon.

Sebaliknya mengacu pada fakta di atas terbitnya Inpres moratorium tidak dapat mewujudkan tata guna lahan yang ideal mengingat lahan perkebunan kelapa sawit yang ada akan terinterupsi pengurusan perizinannya, padahal sifat perizinan teknis perkebunan kelapa sawit adalah saling bersyarat satu sama lain (condition precedence). Pengurusan perizinan dari investasi yang ada justru terhambat dengan terbitnya Inpres moratorium tersebut, mengingat Inpres moratorium menyatakan menunda penerbitan perizinan terkait perkebunan maupun pengolahan kelapa sawit (Sipayung, 2017).

Satmaidi (2015) mengemukakan sejak berlakunya otonomi daerah maka kewenangan terkait tata guna lahan tersebar ke banyak instansi baik di tingkat kabupaten/kota maupun di tingkat provinsi oleh sebab itu secara tata aturan perundangan diperlukan instruksi setingkat presiden atau melalui peraturan perundangan yang tingkatannya lebih tinggi (peraturan pemerintah/ PP atau di atasnya.

Lingkungan yang ideal tidak akan lahir dari lahan terlantar akibat moratorium. Demikian juga, terkait produktivitas lahan, bahwa guna merealisasikan Pasal 33 Undang-Undang Dasar 1945, pemerintah dalam hal ini harus berupaya agar lahan yang ada dapat bermanfaat secara produktif khususnya bagi masyarakat luas (Saharjo, 2013).

Terkait dengan penataan kewenangan dalam pemberian perizinan dalam hal ini masing-masing instansi pemerintah perlu mengesampingkan ego sektoral masingmasing lembaga. Terkait dengan sinkronisasi peraturan perundang-undangan untuk menata kewenangan masing-masing instansi dalam penerbitan izin maka dapat dilakukan dengan dua cara. Pertama melalui sinkronisasi secara kategorial, yakni masingmasing jenis perizinan diuraikan dan 
diinventarisir masing-masing kementerian dan lembaga yang terlibat. Misalnya dalam hal ini kategori izin atas lahan tentu berbeda instansi yang memiliki kewenangan dengan kategori izin yang berkaitan dengan lingkungan hidup seperti AMDAL.

Cara pertama ini mengandung kelebihan yakni akan dapat menemukan kompromi dan melibatkan semua pihak yang terkait dalam pembahasannya, sehingga risiko cacat hukum pada sinkronisasi kategorial ini akan dapat diminimalisir (Priscilia, 2018). Kekurangan pada sinkronisasi kewenangan model kategorial ini adalah pembahasannya akan sangat lama karena akan bergantung pada kompromi dan kesepakatan masingmasing instansi. Sinkronisasi secara kategorial ini juga cenderung tidak akan menghasilkan perubahan yang signifikan karena menggunakan pendekatan kompromis (Yani, 2016).

Cara sinkronisasi yang kedua adalah dengan menggunakan model aturan payung dalam sinkronisasi kewenangan yang timbul dari masing-masing perundang-undangan (White. S., 2016). Persoalannya dalam hal ini adalah OSS lahir melalui Peraturan Pemerintah Nomor 24 Tahun 2018, sedangkan kewenangan instansi yang terlibat dalam pemberian izin bisa saja bersumber dari aturan yang lebih tinggi dari Peraturan Pemerintah, misalnya kewenangan penerbitan izin yang tumpang tindih bersumber dari Undang-Undang.

Sinkronisasi menggunakan aturan payung akan dipandang lebih cepat, efektif, dan dapat menimbulkan dampak yang signifikan jika dibanding dengan sinkronisasi secara kategorial. Sinkronisasi kewenangan penerbitan izin melalui pembuatan aturan payung sebagaimana saat ini dikenal dengan konsep Omnibus Law. Omnibus Law adalah produk hukum yang merevisi beberapa aturan hukum sekaligus melalui aturan payung, disebut sebagai aturan payung karena Omnibus Law secara hierarki perundangan akan lebih tinggi dibanding aturan yang disederhanakan (Yap, 2017).
Upaya Omnibus Law tidak saja sekedar menyederhanakan maupun mengurangi peraturan perundangan melalui pembentukan aturan payung, tetapi juga harus disertai dengan penataan kewenangan. Konflik antar peraturan perundangan yang mengakibatkan tumpang tindih yang menghambat investasi bersumber pada konflik kewenangan. Omnibus Law dalam hal ini akan dapat meringkas tumpang tindih peraturan perundang-undangan sehingga dengan berkurangnya jumlah peraturan perundangan maka jumlah kewenangan yang diberikan peraturan perundangan tersebut juga akan berkurang secara signifikan.

Saat ini dengan terbitnya aturan Omnibus Law (Undang-Undang Nomor 11 Tahun 2020 tentang Cipta Kerja) diharapkan tentu akan berkorelasi dengan pelaksanaan PP Nomor 24 Tahun 2018 tentang Pelayanan Perizinan Berusaha Terintegrasi secara Elektronik dan Instruksi Presiden Nomor 7 Tahun 2019 tentang Percepatan Kemudahan Berusaha. Dengan terbitnya Omnibus Law maka seharusnya pelaksanaan PP Nomor 24 Tahun 2018 terkait pelaksanaan OSS tidak terkendala oleh tumpang tindih kewenangan yang bersumber dari banyaknya peraturan perundangundangan.

Momentum terbitnya Omnibus Law akan berdampak pada lahirnya perizinan terintegrasi sebagaimana dimaksudkan dalam Pasal 1 ayat (5) Peraturan Pemerintah Nomor 24 Tahun 2018. Tidak adanya tumpang tindih kewenangan dan penataan kewenangan yang mengikuti berkurangnya jumlah peraturan perundang-undangan akan dapat mewujudkan makna 'single submission' sebagaimana dimaksudkan dalam Peraturan Pemerintah Nomor 24 Tahun 2018, oleh sebab itu dalam hal ini mengingat pentingnya mewujudkan single submission untuk kemudahan berusaha maka pemerintah perlu segera melakukan penataan kewenangan khususnya dengan dukungan Omnibus Law.

Terwujudnya single submission akan dapat mewujudkan esensi data sharing yang 
akan dapat secara signifikan mengurangi jumlah perizinan karena pada esensinya perizinan adalah alat pengawasan pemerintah sebagai regulator untuk mendapatkan atau memiliki data dari investor (Siswosoediro, 2018). Dengan terwujudnya sifat single submission pada pengurusan perizinan, maka pengurusan perizinan single submission akan dipandang dapat memenuhi kemudahan berusaha karena bersifat terintegrasi.

Demikian juga, dalam hal ini penataan kewenangan akan membuat OSS dapat melaksanakan fungsinya pada data sharing sehingga akan menghindarkan investor dari birokrasi yang panjang pada tahapan pengurusan perizinan maupun menghindarkan investor dari banyaknya jumlah perizinan yang harus diurus oleh investor (Burgos, 2017). Tujuan dari penataan kewenangan adalah melakukan sinkronisasi peraturan perundang-undangan yang melahirkan banyak perizinan yang harus diurus dengan banyaknya kewenangan instansi penerbit yang bersifat tumpang tindih.

Pada akhirnya penataan kewenangan ini harus dapat berkorelasi dengan pelaksanaan Peraturan Pemerintah Nomor 24 Tahun 2018. Dengan pengurusan perizinan yang murah, cepat, sederhana, serta tidak banyaknya perizinan yang harus diurus maka dengan pengurusan terintegrasi model single submission akan melahirkan kepastian hukum bagi investor. Dengan demikian maka OSS akan dapat dikatakan berkorelasi positif dengan tingkat kemudahan berusaha.

\section{Simpulan}

Pelayanan Perizinan Berusaha Terintegrasi secara Elektronik atau dikenal dengan Online Single Submission (OSS) sebagaimana diatur melalui Peraturan Pemerintah Nomor 24 Tahun 2018 belum dapat berkorelasi positif pada upaya untuk mewujudkan kemudahan berusaha di Indonesia meskipun telah mengalami perbaikan dari OSS versi 1.0 pada OSS versi 1.1. Persoalan belum optimalnya OSS disebabkan karena selain OSS hanya dapat dipergunakan untuk mengurus sebagian kecil izin yang memang mudah diurus, sebaliknya untuk mengurus sebagian besar perizinan dalam hal ini investor masih harus melakukan secara manual melalui tahapan dan birokrasi yang panjang.

Selain itu, meskipun telah adanya pengurusan perizinan berbasis pada OSS yang seharusnya memiliki sifat single submission dan dalam hal ini OSS masih belum memenuhi esensi pengurusan perizinan secara single submission itu sendiri. Artinya dalam hal ini OSS belum dapat dipergunakan sesuai yang dimaksudkan dalam Pasal 1 ayat (5) Peraturan Pemerintah Nomor 24 Tahun 2018 karena sifat pengurusan perizinan belum bersifat terintegrasi meskipun menggunakan OSS.

Demikian juga OSS belum dapat melakukan fungsi sebagai data sharing antar instansi sehingga menyebabkan jumlah perizinan yang harus diurus masih sangat banyak (bahkan yang terbanyak di seluruh dunia). Kondisi inilah yang menyebabkan meskipun pemerintah telah menggunakan OSS sebagai sarana pengurusan perizinan namun keberadaan OSS itu sendiri belum berkorelasi positif terhadap kemudahan berusaha di Indonesia.

Persoalan banyaknya perizinan yang harus diurus oleh investor, panjangnya tahapan pengurusan perizinan, hingga tingginya ketidakpastian pengurusan perizinan disebabkan oleh tumpang tindih kewenangan pemberian perizinan yang bersumber pada peraturan perundangundangan. Hal inilah yang menghambat sifat single submission dari OSS itu sendiri. Dalam hal ini OSS tidak akan berfungsi optimal tanpa disertai penataan kewenangan penerbitan perizinan oleh instansi yang terkait.

Penataan kewenangan untuk mendukung optimalisasi OSS harus dilakukan dengan cara melakukan sinkronisasi peraturan perundang-undangan, dalam hal ini momentum sinkronisasi yang tepat dalam rangka penataan kewenangan penerbitan perizinan adalah melalui 
pembentukan Omnibus Law (UndangUndang Nomor 11 Tahun 2020 tentang Cipta Kerja). Dengan adanya penataan kewenangan maka pengurusan perizinan akan lebih mudah baik karena lebih ringkasnya tahapan birokrasi pengurusan maupun karena lebih sedikitnya jumlah perizinan yang diurus.

\section{DAFTAR PUSTAKA}

Arrum, D. A. (2019). Kepastian Hukum Dalam Perizinan Berusaha Terintegrasi Secara Elektronik (Online Single Submission) di Indonesia. JuristDiction, 2(5), 1631-1654. https://doi.org/10.20473/jd.v2i5.15222

Berger, B. (2013). Constraints and Types of Business Interruption in Developing Countries. Iowa Law Review Journal, 99(3), 362.

Brigs, M. (2015). Easy Business Formulation and Regulation for Investors in Southeast Asia. Australian Business Law Review Journals, 59, 119.

Burgos, P. (2017). Easy of Doing Business in Southeast Asia. Ateneo Business Law Review Journals, 36, 109.

Departemen Dalam Negeri Republik Indonesia. (2015). Penyederhanaan Birokrasi Perizinan: Focus Group Discussion (FGD) Departemen Dalam Negeri di Jakarta 4 Maret 2015.

Harun. (2014). Konstruksi Perizinan Usaha Masa Depan. Penerbit SI.

Lahadila, B. (2019). Hantu Berdasi Kendala Investasi di Daerah: Materi Paparan Kepala BKPM dalam Acara Sosialisasi Kemudahan Berusaha Jakarta:

Lestari, S. E., \& Djanggih, H. (2019). Urgensi Hukum Perizinan Dan Penegakannya Sebagai Sarana Pencegahan Pencemaran Lingkungan Hidup. Masalah-Masalah Hukum, 48(2), 147. https://doi.org/10.14710/mmh.48.2.201

\section{$9.147-163$}

Lucas, M. et. al. (2020). 2019 Ease of Doing Bussiness Report (South East Asean) EoDB Series Publishing.

Osenboorg, D. et. al. (2020). World Bank Annual Report 2019 (South East Asean). World Bank.

Ping, L. H. (2017). Simple Licensing as an Incentive for Investors. University of Malaya Law Review Journal, 53, 110.

Priscilia, I. M. (2018). Implementasi OSS pada Badan Pelayanan Perizinan Terpadu (BP2T) Kota Manado. Jurnal Sam Ratulangi Law Review, 1(1), 56.

Pudyatmoko, Y. S. (2009). Perizinan Problem dan Upaya Pembenahan. Grasindo.

Raharjo, A. dkk. (2019). Laporan Tahunan Kinerja KPK Tahun 2019.

Saharjo, B. H. (2013). Pengendalian Hutan dan Lahan yang Lestari. Jurnal Biodiversitas, 17(1), 18.

Sipayung, T. (2017). Moratorium: Sebuah Persoalan Baru. Jurnal Paspi, 2(2), 165.

Siswosoediro, H. (2018). Pengurusan Perizinan dan Dokumen. Visi Media.

Sutedi, A. (2011). Hukum Perizinan dalam Sektor Pelayanan Publik. Cetakan Kedua. Sinar Grafika.

Tim Sosialisasi BKPM. (2019). Buku Panduan Menuju Perizinan Berbasis OSS. Cetakan Pertama. Litbang BKPM.

Tim Sosialisasi OSS. (2018). Buku Panduan Pedoman Pelayanan Berusaha Terintegrasi secara Elektronik (OSS). Kementerian Koordinator Perekonomian.

White. S. (2016). Problem of Licensing Management in Developing Countries. Tamasat Law Review Journal, 49, 172.

Yani, A. dkk. (2016). Perizinan Terpadu. Cetakan Pertama. Unmal Press. 
Yap, K. (2017). Comercial Aspect on Omnibus Law. Hongkong Babtist University Legal Journal, 34, 83.
Yong, D. (2019). Data Sharing as a Legal Solution. Singapore Law Review Journal, 36, 306. 